\author{
RADOSŁAW PIĘTKA
}

Adam Mickiewicz University, Poznań

\title{
"WHEN THE STARS ARE GLITTERING WITH GOLD UP IN THE SKY...” JEWELLERY METAPHORS IN DESCRIPTIONS OF SKY PHENOMENA IN ROMAN LITERATURE
}

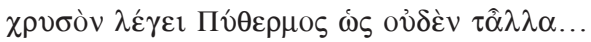

Ananios, fr. 1, 2 (West)

\begin{abstract}
Piętka Radosław. "When the Stars Are Glittering with Gold up in the Sky..." Jewellery Metaphors in Descriptions of the Sky Phenomena in Roman Literature.

The paper traces the use of metaphors and comparisons concerning jewellery in the descriptions of the sky in Roman literature, most of all in poetry. As it is shown in the paper, many of those poetic devices served as a means highlighting the vividness and perfection of the natural sky phenomena. Analysis of jewellery imagery helps also to demonstrate the occurrence of some changes in descriptive conventions and aesthetic attitudes in Roman literature.
\end{abstract}

Keywords: astronomical literature; metaphor; jewellery.

There is nothing more natural than speaking in the same breath of metaphoric quality and astronomy. The Sun, the most important celestial body from the earthly point of view, is in a way a master for any figurative expressions, metaphor of metaphors; all metaphors are naturally "heliotropic", as thinking about a metaphor begins with the Sun, which appears and disappears, and constantly "revolves" around the Sun. ${ }^{1}$ Still, the relationship of the metaphorical way of speaking with the universe has several other motivations. Cosmic spheres were ascribed an unusualness that would not allow outright utterances; it can be noted that catasterism, a subject of many ancient astronomical texts, is an operation resembling metaphor-making, "figuring" earthly phenomena to the sky. However, that's not all: the objective of the metaphor is to acquire clarity, which is considered as the most important feature of celestial bodies; Quintilian remarks (using metaphors in his exposition) that metaphorical

${ }^{1}$ Vide Derrida 1974, 52-53; Derrida 1982, 250-251. Derrida refers here to considerations on the Sun from Topics by Aristotle (131 b 22-31 or 20-30). 
"figuring" of meanings is supposed to make terms clearer, and the metaphor sometimes specifically "enlightens" the speech ("ita iucunda atque nitida ut in oratione quamlibet clara proprio tamen lumine eluceat"; Quint. VIII 6, 4). ${ }^{2}$ In addition, ancient thinking about the sky is dominated by the principle of analogy - from times immemorial it was accompanied by a belief in the relationship between earthly and celestial phenomena. Hence, the word "metaphor" in the title must be treated as a conventional term denoting a vast "domain of analogy" composed not only of classical metaphors, but also comparisons, and that astronomical imaginary "figuring", called "catasterism." It would be difficult to present here all the manifestations of the ancient belief in that the universe is a peculiar analogon of earthly realities. Suffice it to mention just a few of the best known Greek philosophical conceptions based on this belief: pre-Socratic philosophers of nature assume that the universe is in fact homogenous, made of the same element, and led everywhere by the same powers; ${ }^{3}$ to Pythagoreans we owe an observation that the same harmony that exists in the universe can also embrace the human soul, which has widely borne fruit through the centuries with an accepted, though variously conveyed, conception of the man as microcosm. ${ }^{4}$ In a Pythagorean-Platonic version of this view passed down by Plutarch, three components of human being were combined with three astronomical objects: the body with the Earth, the soul with the Moon, and the mind with the Sun (Mor. 943A).

The notion of the "universe", that is an order, a system characterised by beauty, but also "ornamentation" or "jewellery", was used for the first time by the Pythagoreans to denote the world (and first of all the sky). ${ }^{5}$ Subsequent, even more scientific theories generally indirectly or directly confirm most of this "cosmic" worldview. The closed globe of the Aristotelian (and subsequently Ptolemaic) universe is a place close to the Earth, tamed and friendly. Perhaps except for the agnostics, ${ }^{6}$ the worldview of the people of past epochs was

${ }^{2}$ According to contemporary scholars' observations, one of the most important functions of the metaphor is conveying "the vividness of phenomenal experience"; Ortony, Fainsilber 1989, 181).

${ }^{3}$ Vide Long 1999, 11; Algra 1999, 59; Laks 1999, 252.

${ }^{4}$ Terminological priority, as is frequently believed (vide e.g. Reale 1989, 174-175), in this

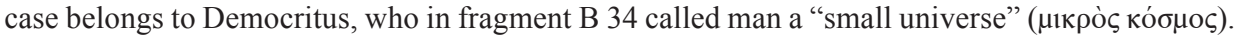
However, it cannot be ruled out that David of Armenia, a Neoplatonist of the $6^{\text {th }}$ century, to whom we owe this information, meant Democritus the Neoplatonist of the $3^{\text {rd }}$ century CE, and not Democritus of Abdera. For controversies in this matter, see Finkelberg 1998, 120-122. For the idea of the microcosm in antiquity, vide e.g. Conger 1922, 1-28; Allers 1951; Guthrie 1967; Wright 1995, 56-74; Piętka 2009, 38-48.

${ }^{5}$ Also here there are lots of controversies - it is alleged that the essentially Platonic concept of the "universe" as "universal symmetry" was attributed to Pythagoras ex post, as it were. For more on this, vide Finkelberg 1998, 128, footnote 92.

${ }^{6}$ For redefinitions that occurred in the ancient image of the universe due to gnosticism, vide Jonas 2001, 241-265. 
dominated by a conviction that there existed a strict "positive" bond between earthy life and celestial phenomena, a peculiar cosmic "liking"; " probably the most prominent example of this idea was the words attributed to Hermes Trismegistus from the famous Emerald Tablet, which for several centuries kindled the imagination of European thinkers, occultists, alchemists, and astrologers. The hermetic sentence stated that "whatever is below is similar to that which is above, and vice versa." and made repeated references to it in their literature. Cosmic similarities were discovered with particular fondness, especially in the three spheres of human activity: ethics, politics and aesthetics.

To illustrate this issue with regard to ethics, it's best to use Cicero's words, according to which human life consists of "imitating the order of the sky in terms of the way and constancy of one's own life" ("[...] credo deos inmortales sparsisse animos in corpora humana, ut essent qui terras tuerentur quique caelestium ordinem contemplantes imitarentur eum vitae modo atque constantia"; De senect. XXI 77). Later on, similar observations will become a particular domain of stoics, an inseparable component of their ethics based on the belief in sensible order obtaining in the whole universe. Marcus Aurelius, in one of the most obvious examples, places in his spiritual diary the following order: "Look round at the courses of the stars, as if thou wert going along with them" (VII 47; translated by George Long). In "stoicising" Roman poets who exploited astronomical topics, this type of thinking is reflected, e.g. in the term honos, used to denote the degree of star brightness." "

The structure of the universe would often serve as justification for various systemic solutions; The Sun is after all a perennial symbol of monarchy; thereby the phenomenon of the double Sun, although exceptional, was treated by the Romans as an analogy to the institution of the consulate, ${ }^{10}$ and five types of stars would correspond to five social classes in Rome, as is presented by Marcus Manilius in his astronomical poem (Astr. V 734 seq.). ${ }^{11}$

The sky (caelum), imagined as a piece of art, was presented in Roman literature as a sculpture - caelatura, in accordance with the etymology suggested by Varro in Menippean satire Postumi cui seplasia fetet (Sat. Men.,

${ }^{7}$ As terminus technicus the term liking $(\sigma \nu \mu \pi \alpha \dot{\theta} \theta \varepsilon 1 \alpha)$ belonged to the vocabulary of various philosophical schools, from Peripatetics to Stoics to Neoplatonists, assuming different shades of meaning (vide Reale 1989, 261-262). In Manilius can be found similar Latin counterparts of this term (mutua foedera, Astr. I 252; alternus consensus, Astr. II 63).

${ }^{8}$ Vide Bugaj 1991, 120 and 124-125.

${ }^{9}$ Vide Santini 1977, 40.

${ }^{10}$ Vide Gallagher 2001, 509-519. Inspiring for these considerations were surely Plato's conceptions; for a Platonic vision of the state as universe, vide e.g. Vernant 1982, 128-129.

${ }^{11}$ Vide Landolfi 1991, 247-258. Generally, on political themes in Manilius' astronomical poem writes, among others, Bajoni 2004, 98-107. 


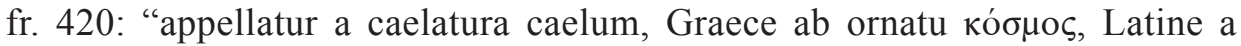
puritia mundus"); ${ }^{12}$ where caelatura can also mean a relief, and a product of a toreutic, i.e. a printmaking or even engraving work. Therefore, it's not surprising that individual sections of the starry sky, like Orion's Belt or the Milky Way, were expressed using a vocabulary related to the term caelatura. ${ }^{13}$ Other terms from this artistic scope of meaning used with reference to the universe are first of all "spectacle" - spectaculum (e.g. in Manilius, Astr. I 737: "spectacula mundi") and "building" expressed as templum (e.g. De Rep. VI 15 by Cicero), aula deorum (Awienus, Phaen. 1508), or fabrica, according to Firmicus Maternus (Mathesis VIII 1, 6): "So, look [...] at the sky with your eyes wide open, and let your soul always investigate this most beautiful construction, the result of divine work" ("Intuere itaque [...] patentibus oculis caelum, et pulcherrimam istam divini operis fabricam animus tuus semper aspiciat").

Should we want to find an answer to the question of which mechanisms govern perception of the universe as a product of artistic creation, one would need to refer to contemporary aesthetics that diagnose the way of perceiving nature by Man. Emily Brady, a scholar dealing with how imagination influences the aesthetic perception of the image of the sky (and the whole of nature not transformed by people in general), has distinguished several varieties of imaginary operations. The most useful in this case seem to be her analyses referring to the so-called "projective imagination" and "amplifying imagination." ${ }^{14}$ Projective imagination is the one that projects onto the nature the objects of human world, and thereby it is responsible for the anthropomorphisation of the natural world. The objective of this type of activity must be understood as follows: in order to experience the beauty of the nature, the latter must be equipped by means of imagination with shapes the man is familiar with - in this way, as Brady suggests, there appeared images of star constellations. As one of the linguistic equivalents of the operations performed by the projective imagination could perhaps be regarded the metaphor, a procedure allowing perception of a phenomenon "as something different." 15 The amplifying imagination enriches images provided by nature with a certain

\footnotetext{
${ }^{12}$ Varro ascribed this idea to Aelius Stilo: "caelum dictum scribit Aelius quod est caelatum [...]" (De ling. Lat. V 18). Later on, this etymology was also referred to by Pliny the Elder (Nat. Hist. II 1, 8) and Manilius (Astr. I 679-680). Vide Volk 2009, 20.

${ }^{13}$ For astral metaphors related to the verb caelare, vide Hermann 2007, 46-47.

${ }^{14}$ Vide Brady 1998, 143.

${ }^{15} \mathrm{Cf}$. Brady 1998, 143. In her later monograph on the aesthetics of the natural environment, Emily Brady even distinguishes a "metaphorical imagination" as a separate phenomenon in the realm of nature perception that allows binding together images of different objects from two areas of reality (e.g. rocks and cathedrals); vide Brady 2003, 153. This type of operation, however, is clearly related to transformations performed by "projective imagination."
} 
narrative context; ${ }^{16}$ thanks to this, sky images are accompanied by catasterism stories based on mythology.

As it turns out, the metaphorised story of the "artistically" presented universe can also be one of goldsmith's art: the universe imagined as a "factory" mentioned by the author of Mathesis, is equally an "architectonic structure", "building", and "craftsman's workshop", as the word fabrica was also understood. So one can imagine the world even as goldsmith's workplace. After all, pieces of jewellery art are among the constellations known to ancient sky observers, first of all the Southern Crown (Corona Australis) and more famous Northern Crown (Corona Borealis), called the Wreath of Ariadne. There is disagreement concerning the real image of the archetype of this constellation: the shape in the sky could have represented not only a diadem, but also an ordinary flower wreath ${ }^{17}$ or according to the most original contemporary theory - it supposedly represented Mycenaean cult horns known from the palace at Knossos. ${ }^{18}$ Among the Greek authors writing about stars who had no doubts was the Pseudo-Eratosthenes, who in Catasterismi (5) described the crown as a work of Hephaestus, carved from gold and embellished with precious Indian stones. ${ }^{19}$ Hyginus in his mythographic and astronomical compendium (De astr. I 5,1$)$ writes in virtually identical words about the crown made from gold and Indian jewels by Vulcan illuminating Theseus' way in the labyrinth:

Corona. Haec existimatur Ariadnes fuisse a Libero patre inter sidera conlocata. Dicitur enim in insula Dia cum Ariadne Libero nuberet, hanc primum coronam muneri accepisse a Venere et Horis, cum omnes dei in eius nuptiis dona conferrent. Sed, ut ait qui Cretica conscripsit, quo tempore Liber ad Minoa venit, cogitans Ariadnen comprimere, hanc coronam ei munere dedit; qua delectata, non recusavit condicionem [stupri]. Dicitur etiam a Vulcano facta ex auro et Indicis gemmis, per quas Theseus existimatur de tenebris labyrinthi ad lucem uenisse, quod aurum et gemmae in obscuro fulgorem luminis efficiebant.

More modestly, as just gold, is the crown presented by Catullus (LXVI 60-61: ,[... ] ex Ariadnaeis aurea temporibus / fixa corona foret") ${ }^{20}$ and Ovid in Fasti (III 516). In Metamorphoses, Ovid describes the catasterism of the wreath of Ariadne, i.e. as a moment when the precious stones are transformed into glittering stars: "[...] ut perenni / sidere clara foret, sumptam de fronte coronam / immisit caelo: tenues volat illa per auras / dumque volat, gemmae nitidos vertuntur in ignes / consistuntque loco specie remanente coronae" (Met. VIII 177-181). As shown

${ }^{16}$ Vide Brady 1998, 144.

${ }^{17}$ Among authors who refer to Ariadne's Crown as a "wreath" (serta) are among others Germanicus (Aratus 73 and 85), Seneca (Herc. Fur. 18) and Avienus (Phaen. 1080-1081, 1150, 1211)

${ }^{18}$ Vide Schavernoch 1983, 48-49; quoted after Hermann 2001, 24.

${ }^{19}$ India, as a land flowing with gold and jewels appears e.g. in Manilius, Astr. IV 671-674.

${ }^{20}$ Vide Clarke 2003, 35. 
by archaeological studies, "Ariadne's crown made by Hephaestus in the form of a rose-wreath is not a fancy; delicate gold wreaths with gemmed flowers were found in the Mochlos hoard." ${ }^{21}$ In Manilius' Astronomica, the description of the diadem is even richer, and the additional details are imaginative in character, as this Roman poet places in the middle part of the constellation - contrary to the data provided by sky observation - the brightest star as a jewel that crowns the diadem. ${ }^{22}$ It's worth mentioning that the Wreath of Ariadne, a constellation usually described in Latin poetry as "shiny", "clear" (clarus), is in reality composed of stars whose degree of brightness is currently low.

As goldsmith's ware can be considered another constellation - the Bowl (Crater), situated in the vicinity of the Raven and the Serpent (i.e. Hydra). In the story told by Ovid, a water vessel taken by the Raven is golden, inauratum (Fasti II 251) - a detail unknown to Pseudo-Eratosthenes or Hyginus. Manilius, apparently inspired by Ovid, enriches his description: "Crater auratis surgit caelatus ab astris" (Astr. V 235). The Bowl was "carved" or "engraved", ${ }^{23}$ as the word caelatus, bearing in mind the etymology given by Varro, can mean also that the cup was made of matter supplied by the sky, i.e. in this case a cosmic metal of golden stars ("ab auratis astris").

One should remember, however, that the stars alone are expressed metaphorically in Latin poetry as "gold" because of their colour or similarity to precious metal, no matter which constellation they form. For instance, as in Aeneid (XI 832-833): "tum vero immensus surgens ferit aurea clamor / sidera [...]" or in an anonymous, extremely sparkling poem quoted by Servius (De centum metris 466, 31): "[...] sidera cuncta micant decore lucis aureo."

No wonder that in one of the poetic ecphrases the entire night becomes gold due to glittering stars (Valerius Flaccus, Arg. V 562-566):

nec quisquam freta nec patrias iam respicit urbes,

sed magis ad praesens itur decus. incita cristas

aura quatit, variis floret via discolor armis,

qualis ab Oceano nitidum chorus aethera vestit,

qualibus adsurgens nox aurea cingitur astris.

Supplementary, as it were, to this motif in Roman poetry, treating stars as golden ones, is a description in which the situation gets reverted: it's the goldsmith's piece of art, as a work of human hands, that appears as comparandum in an astral comparison, as is presented by Silius Italicus (Punica VII 634-640):

\footnotetext{
${ }^{21}$ Graves 1992, 347.

${ }^{22}$ Roman descriptions of the Northern Crown constellation are analysed in detail by Hermann 2001, 57-60. Cf. also Le Boeuffle 1977, 99-100 and 191-192.

${ }^{23}$ This version, one with engraved Bowl, was chosen by the English translator of Astronomica: "The Bowl comes into view, chased with the gilt of its stars" (Manilius, Astronomica 1992, 319).
} 


\begin{abstract}
Venerat ad bellum Tyria Sidone, nepotum excitus prece, et auxilio socia arma ferebat, Eoa tumidus pharetrati militis ala, gens Cadmi, Cleadas; fulva cui plurima passim casside et aurato fulgebat gemma monili, qualis ubi Oceani renovatus Lucifer unda laudatur Veneri et certat maioribus astris.
\end{abstract}

Sometimes, a mythical, constellation-related story provides additional justification for jewellery plots that appear in its description. The wonderful bull that according to the myth Zeus transformed himself into to abduct Europa has very "artistic" horns resembling precious stones $;{ }^{24}$ so, it was not difficult to imagine it in a starry version with gold horns - and such is the Taurus constellation presented by Vergil (Georg. I 217-218):

Candidus auratis aperit cum cornibus annum

Taurus et averso cedens Canis occidit astro. ${ }^{25}$

As natural one would need to consider a motivation for the "goldsmith's" epithets appearing in the context of astral Aries, which according to traditional descriptions wears a "golden fleece." What can be found here is dependencies similar to those that shaped the myth of Europa; mythological interpretations concerning the origin of the golden fleece leave no doubt that it was a solar symbol: an account of the fall of Helle (identified with the goddess of the Moon) into the sea, and the triumphant flight of the golden ram presents a victory of the solar deity over the lunar goddess, and the golden fleece is an original garment in which Zeus enters the heavens. ${ }^{26}$ No wonder that the god of the Sun is sometimes seen as a wearer of a golden robe embellished with precious stones, as it is put in Seneca's Medea (570-574). The gold of astral Aries is therefore a sign of the highest power. For Manilius, the Aries constellation is the "princeps" (i as a "leader" opening a zodiacal year), Seneca (Thyestes 223) speaks about a

${ }^{24}$ Vide Graves 1992, 194. Among Roman poets, the matter is presented in this way by Ovid (Met. II 855-856). In an earlier text on this subject, the epyllion Europa by Moschos, there is only an allusion to a jewellery-decorated bull-Zeus: before the narration concerning the abduction of Europa there appears an ecphrase of the female character's basket made from precious stones, part of which is a gold image of the ruler of gods.

${ }^{25}$ Someone could notice that the effect of "goldenness" was enhanced here thanks to such an arrangement of words which corresponds (approximately) to the definition of the "golden verse" (two adjectives, two nouns, and a verb between them). However, this would be an anachronism, as this term was formed in modern times, and its presumed ancient equivalent is not so much "gold" as "polished/beautiful verse" (teres versus) only described in Ars grammatica by Diomedes (IV c. BCE).

${ }^{26}$ Vide Graves 1992, 230. A similar interpretation of a cosmic conflict accompanies the myth of Europa representing the Moon, and Zeus, the solar bull; vide Graves 1992, 197. 
golden Ram, saying that it is "specimen antiquum imperi", just like Artemidorus (Oneirocr. 27, 3) and Ammianus Marcellinus $(19,1,1)$ believe. ${ }^{27}$

The way in which Manilius describes Aries ("Aurato princeps Aries in vellere fulgens"; Astr. I 263), suggests that we are dealing here with an additional, metaphorical function of auratus, meaning luminosity, ${ }^{28}$ beauty and extraordinary nature (all the more so as contrary to the poetic description the ram was transferred into the sky without its golden fleece $\left.{ }^{29}\right)$. The case is similar with such constellations as Orion (Astr. V 723) or Olor, Cygnus (Astr. V 388), presented by Manilius as "golden", too. Considering that elsewhere in the poem Cygnus was ascribed epithets "white" ("niveus"; Astr. I 339) and "shiny" (and actually: "with shiny wings" - "nitidis alis"; Astr. V 366), this constellation could even be imagined as an object made of chryselephantine. Coming back to the rams: an animal of "golden fleece" ("aurato vellere"; Aratus 532; "villis auratis"; Aratus - Fragmenta 114) on a "golden back" ("pecudis... aurea terga"; Aratus Fragmenta 144) is virtually the only goldsmith's motif in Germanicus' Aratea (incidentally, in the extant fragments of a translation of Aratus' Phenomena made by Cicero, jewellery metaphors do not appear at all). Characteristic in this respect is Germanicus' description of the constellation Boötes including the star Arcturus; this description makes one only guess that Arcturus, in fact, one of the brightest stars of the northern part of the sky, is a kind of a jewel, a precious stone in the brooch that fastens up the imaginary coat of the figure of Boötes. ${ }^{30}$ Such a camouflaged way of presenting jewellery content is in line with the manner of the original, the Greek Phenomena, in which goldsmith's art appears only in the form of quite dim allusions. For instance, Aratus (Phaen. 530) with reference to the structure of planetary spheres uses a metallurgical verb ко $\lambda \lambda \alpha \dot{\alpha} \omega$ (to bind, solder), which is used in the goldsmith's context (Pind. Nem. VII 78), as it describes a combination of gold and ivory in a crown. ${ }^{31}$

Authors of Roman translations of Aratus' poem are usually as reserved as their prototype; ${ }^{32}$ the exception is Avienus' version, the most independent and eccentric paraphrase of the Phenomena, much more extended than the original Greek text. A telling example is the above mentioned constellation Boötes: in Avienus (Phaen. 270-271), the star Arcturus was put in an honourable place of the "Golden Dog" ("aurea cingula") that Boötes' robe is decorated with. Avienus

${ }^{27}$ Vide Wagenvoort 1966, 1669-1670.

${ }^{28}$ Vide Sacchetti 1993, 100-101.

${ }^{29}$ Discussion in this matter: Traglia 1984,324 , footnote 13 , in relation to remarks included in the article by Montanari Caldini (1976, 37-38).

${ }^{30}$ Vide Hermann 2001, 56.

${ }^{31}$ Vide Gee 2001, 529-530.

${ }^{32}$ Aratus' descriptions of constellations were sometimes referred to as "dry" or "bland"; vide Zanker 1987, 97. Generally, for the topic of Aratus' technique of star descriptions vide Semanoff 2006, 156-177. 
does not shy away from jewellery metaphors, which is proven by much evidence in his work: the Moon (Luna) is for him a "golden torch" ("fax aurea"; Phaen. 452), and the Pleiades shine with "golden red" ("rubor aureus"; Phaen. 572) - perhaps this expression should be understood such that just as red gold is less pure (as it is mixed with copper), so the Pleiades shine with dimmed light. The metaphorical nature of the expression concerning the Moon was slightly blurred because of Plutarch's (Mor. 935A) information that the Moon's surface is presumably covered with the material, glittering silver and gold. ${ }^{33}$ A more conventional epithet suitable for the Moon would be the adjective argenteus, consistent both with the ancient philosophical tradition and that concerning astrology and alchemy, ${ }^{34}$ and the modern linguistic custom which has created the phrase "silver globe." In Roman poetry, it is not hard to find relevant examples: Leander in Ovid's Heroides (XVIII 71) is praying to Luna calling her "argentea." It should be noted, however, that before Avienus one who came up with the idea of calling the Moon "golden" was Vergil (Georg. I 430-431):

At si virgineum suffuderit ore ruborem,

ventus erit: vento semper rubet aurea Phoebe.

A path of similar associations was followed by Silius Italicus (Punica XIII 556-557); when he wanted to find a suitable comparison for the last tenth gold gate of the other world, he compared it with the Moon:

Extrema hinc auro fulgens iam lucis honorem sentit et admoto splendet ceu sidere lunae.

After Avienus, the "golden" epithet was attributed to the Moon by Martianus Capella (De nuptiis Philologiae et Mercurii IX: De Harmonia 902):

Aurea flammigerum cum Luna subegerit orbem,

rosis iugabo lilia.

In addition, Avienus' original invention is the unusual metaphor of "diamond" (or possibly some other durable substance, e.g. iron or rock, although the

${ }^{33}$ Later on, Saint Bonaventure will announce that the metals and jewels hidden underground are an effect of the penetration of the Sun's and stars' rays under its surface ... (vide Eco 1987, 64). It's worth mentioning here that perhaps the most famous goldsmith's allegory in the history of culture, i.e. Vergil's golden bough - a solar symbol and a specific tool used (similarly to the fern-seed) for detecting gold underground (vide Frazer 1994, 797-799) - is in a way the opposite of catasterism: as part of the Sun was transferred to the Earth (by lightning striking against a tree, as was believed).

${ }^{34}$ For theories combining celestial bodies with metals, vide Halleux 1974, 151-156; as results from the comparisons mentioned here, silver is invariably a "lunar" metal. 
context implies a rather jewellery-related meaning), indicated by the adjective "adamanteus" (Phaen. 1509 and 1555). To read the meanings hidden behind the image of the Sun moving about in a diamond chariot ("curru adamanteo"), ${ }^{35}$ one would surely need to take into account such diamond features as "extraordinary glare", "unalterable nature", and "invariability"; additionally, as an essential diamond feature in this context can also be deemed "high value" - and if we use the Aristotelian scheme explaining the metaphor mechanism (Poet. 1457b 16-31), we will discover another analogy: just as the diamond is the most precious earthly object, the Sun is the most perfect celestial body. Surely similar in meaning is the "sky axis metaphor" ("Caelum super, aula deorum, / axe adamanteo convolvitur"; Phaen. 1508-1509) used by Avienus, which is likely a reminiscence of a phrase appearing in one of Pindar's fragments (fr. 88, $6=33$ c Sn.) telling about the Earth supported by "columns of diamond foundations"

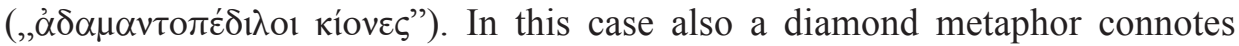
extraordinary nature, and first of all durability. In this sense, Manilius speaks about "adamanteis catenis" (Astr. I 923), "unalterable bonds" of fortune (in this case surely "iron" rather than "diamond").

A similar amplification as in Avienius is the case in another example of Greek astronomical work, namely in Apuleius' poem De mundo, which is a

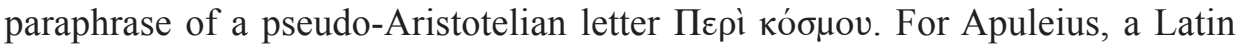
equivalent of the Greek term kosmos is not ornatus, but "necklace" (monile):

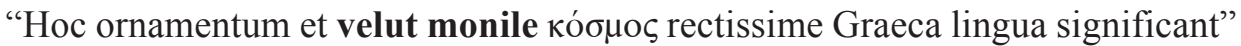
(De mundo 29). To Apuleius we also owe a slightly more elaborate comparison of the palace of Persian kings to the universe than in the Greek original, and this palace is described as a kind of piece of jewellery art (De mundo 26):

Cambyses et Xerxes, et Darius potentissimi reges fuerunt; horum praepotentiam, quam ex opibus collegerant, lenocinium vitae effecerat celsiorem, cum eorum alter, apud Susam et Ecbatanas ut in fano quodam sacratus, nulli temere notitiam oris sui panderet, sed esset circumsaeptus admirabili regia, cuius tecta fulgerent eboris nive, argenti luce, flammis ex auro vel electri claritate.

"However, one must know - adds Apuleius (De mundo 27) - that the relation between this Persian kingdom and the kingdom of the universe is the same as one between the greatest god and the most sublime god, or one between a languid person and the most wicked person." The difference between the original and Apuleius' translation is that silver was added to the set of jewellery materials.

\footnotetext{
${ }^{35}$ This image could be inspired by a "jewellery" description of the Sun's chariot, which is present in Ovid's Metamorphoses (II 107-110). In Boethius (De cons. II, metrum VIII, 5-6), the Sun drives a golden chariot: "Phoebus roseum diem / curru provehit aureo." The Sun's golden vehicle made by Hephaestus is a topic know from archaic Greek poetry (Mimnermus, Stesichorus), but this vehicle is a bowl sometimes used as a bed (i.e. another goldsmith's ware in the sky). This subject is discussed by Athenaus, Deipn. XI 469 c-470 d. Vide Bartol 1997, 7-17.
} 
Apparently, the description following an "artistic" form is linked in Apuleius with a political metaphor, and in some ways also an ethical one; besides, it resembles a description of the golden and silver palace of the Sun in Ovid's Metamorphoses (II 1-4) including its emerald throne (II 24). This solar episode from Metamorphoses is significant insofar as the chariot of Helios mentioned above is exceptionally saturated with golden colour (II 107-110):

\begin{abstract}
Aureus axis erat, temo aureus, aurea summae
curvatura rotae, radiorum argenteus ordo;

per iuga chrysolithi positaeque ex ordine gemmae

clara repercusso reddebant lumina Phoebo.
\end{abstract}

This image leaves no doubt that gold means a jewellery material here, while in other cases poetic descriptions of the Sun give no certainty whether by any chance this is not just a golden colour. This might be the case in Catullus $(63,39-40)$ :

Sed ubi oris aurei Sol radiantibus oculis

lustravit aethera album $[\ldots]$

This time, it is not a description of the Sun's deity, but one of its appearances, as Catullus presents "the golden-faced Sun" as translated by Anna Świderkówna, ${ }^{36}$ watching the world with its gleaming eyes. "Gold is the most obvious metaphor accompanying the Sun, ${ }^{37}$ which is attested to, among others, by the following examples: "Per duodena regit mundi sol aureus astra" (Georg. I 232), "Quod superest, ubi pulsam hiemem sol aureus egit" (Georg. IV 51); in Manilius (Astr. I 644), the Sun is called "aureus orbis"... Where Martianus Capella (De nupt. II 188) desires to present the most essential features of the Sun, he will not fail to mention its golden glare:

Solem te Latium vocitat, quod solus honore post patrem sis lucis apex, radiisque sacratum bis senis perhibent caput aurea lumina ferre, quod totidem menses, totidem quod conficis horas.

Among many expressions characterising the Sun in the hymn of praise in its honour in De nuptiis Philologiae et Mercurii (II 116), other references to wellknown metaphors of the jewellery repertoire could not be absent:

\footnotetext{
${ }^{36}$ Catullus 1956, 68. Catulus' epithet aureus $(63,39$ and 66, 60) is considered by Clarke (2003, 34-35) as a "golden colour" symbolising divine power.

${ }^{37}$ Vide Halleux 1974, 151-156. Among the sixteen Greek texts that the French scholar analyses here, fifteen of them associate gold with the Sun; an exception are Homeric allegories from Codex regius 2556, which describe the Sun as $\tau$ ì $\ddot{\eta} \lambda \varepsilon \kappa \tau \rho \rho v$, i.e. amber, or (more likely) alloy of gold and silver. On the meanings and contexts related in ancient Greece with the word "electron" wrote Buttmann (1820, 38-59).
} 
et iam tunc roseo subtexere sidera peplo coeperat ambrosium promens Aurora pudorem, cum creperum lux alma micat, gemmata Dione cum nitet, aurato vel cum fit Phosphoros astro.

Apparently, even when the Sun is not described directly as "golden", it is surrounded by a sufficient number of semantic signals suggesting this gold colour; this can include gold-haired goddesses of the seasons, or a crown full of glow, evoked in a description by Valerius Flaccus (Arg. IV 90-95):
Interea magni iamiam subeuntibus astris
Oceani genitale caput Titania frenis
antra sonant, Sol auricomis urgentibus Horis
multifidum iubar ${ }^{38}$ et bisseno sidere textam
loricam induitur; ligat hanc qui nubila contra
balteus undantem variat mortalibus arcum.

The above examples present the Sun as a monarch of the world, surrounded by previous attributes of its power; this role can also be performed by Jupiter, about which we are informed again in the work of Martianus Capella (De nupt. IX: De Harmonia 911-912), showing a relationship between royal insignia and the appearance of the universe:
Te nunc astrisono carmine, Iuppiter, quo gemmata poli volvere sidera suevit lege rata sacra recursio, praefandum veneror, quippe potissimus nectis sceptrifero sub diademate omnigenum genitor regna movens deum, mundum perpetuo dum rotat ambitu mens, quam sidereo sufficis impete. te nam flammigeri semina fomitis spargentem referunt astra micantia; te Phoebea sacro munere lumina, terris purpureum dum renovant iubar, testata ambrosium splendificant diem; Cynthia noctis honos lampade menstrua auratis rubuit praevia cornibus; sub te plaustrilucis luminat ignibus anguis Parrhasias disiciens feras.

Against this background, not only Avienus" "diamond" metaphors, but also a certain passage from Manilius' Astronomica become original (IV 923-928). An image of gold and diamond appears here in a completely new context, not related directly with the appearance of the sky:

\footnotetext{
${ }^{38}$ Iubar in this context is no other than "diadem" or "coronet."
} 


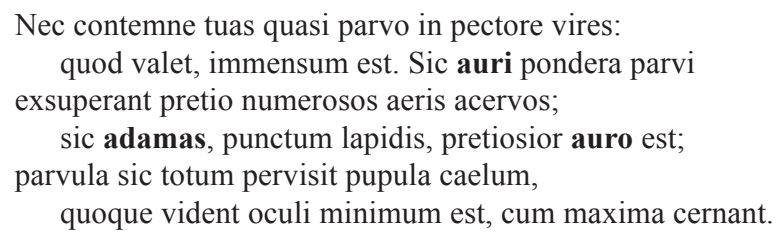

The above exposition refers to a relationship between the portion and the whole, microcosm and macrocosm, well-known from ancient deliberations on the universe, ${ }^{39}$ but also it touches upon a theme so characteristic of Manilius' poem concerning the methods of getting to know the sky, i.e. an epistemological theme. ${ }^{40}$ Here, the most important feature of gold and diamond is not their appearance, but the price, and the comparison does not point to what's in the sky, but what's in the man. However, one can presume that in constructing this description Manilius remembered about the jewellery splendour of the sky, and selected his comparisons following a conviction that things similar can be known by the similar. In this way, the jewellery subject was given in Astronomica a completely new setting detached from purely aesthetic justifications.

Any jewellery metaphors mentioned here connote such features of the constellations (including the Sun and the Moon) as brightness, beauty and perfection, as well as the highest price - while gold and jewels represent overabundance on Earth, "astral jewellery" is to make one want to strive for higher values ${ }^{41}$ Here come to mind Ernst Gombrich's observations on the method of metaphorical representation of values by the artists of bygone epochs. In old-time art - as Gombrich asserts - visualisation of values was based on uncomplicated identifications, and it was only transformations of taste, modifications in cultural systems of values, that have separated aesthetic consciousness from simple reaction of the senses. ${ }^{42}$ A relationship of this consciousness with the "simple reaction of the senses" consists in that what's clear and glittering is instinctively perceived as perfect and good also in the supernatural sense. Therefore, "gold" is one of the most universal metaphors transferring onto a determined object any varieties of perfection..$^{43}$ A protagonist of Gombrich's essay is a Renaissance theoretician of painting, Leone Battista Alberti, who appealed (referring to Plato

${ }^{39}$ For the motif of microcosm and macrocosm in Manilius, see: Salemme 1983, 34-40; Hübner 1984, 252-253.

${ }^{40}$ Vide Piętka 2005, 143-151; Volk 2009, 224.

${ }^{41}$ Vide Baldry 1952, 86.

${ }^{42}$ Vide Gombrich 1974, 303-304. On "naive" perception of glare that reaches our eyes from outer space wrote similarly Arnheim 2004, 342-343. Cf. also Rzepińska 1983, 110-172 (on the aesthetics of glare in Middle Ages).

${ }^{43}$ Vide e.g. Halleux 1974, 146, addressing justifications which Neoplatonist Hierocles found for the fact that one of the Pythagorean treaties was entitled The Golden Verses. 
or Roman Platonist Cicero) to leave places of cult devoid of golden decorations. Glare was to be replaced by simplicity. Perhaps, however, the first stage of departing from the criteria of valuation based on "simple reaction of senses", the reaction related to aesthetic and axiological role of "gold", is reported by Plato (Hipp. Maior 289E). Among the ingenuous answers that Sophist Hippias gives to Socrates' question about "what is beauty in itself", there appears a argument consistent with a popular way of thinking concerning gold that can make any object beautiful. Socrates, however, is looking for another answer to this question, an answer which breaks off the sensual perception of beauty. Further advances on this path were made by Platonists of subsequent epochs, for instance Boethius (De cons. II 5) who considered the beauty of precious stones as "lower order beauty" as it can be wholly mastered, while the glare of stars is a universal beauty meant "for all." Boethius, like Plato, is distrustful of "simple reaction of the senses"; so he performs a theoretical delimitation of impressions related to jewellery and astronomy. ${ }^{44}$

A question can be asked whether in the relationship with these timid corrections made by the philosophers there could occur any changes in the descriptions of the sky constructed in belles-lettres. Some evidence is provided by the same text by Boethius, which addresses distrust of the glamour of material riches: in one of the poetic parts of De consolatione..., as we have seen, it was nonetheless still possible to use a conventional metaphor of "the Sun's golden chariot" (see footnote 34). Perhaps to this coincidence should not be attributed too much significance, but it is allowable to put forth a hypothesis that jewellery metaphors in sky descriptions will over time become to a lesser extent a symbol or values and carrier of axiological content, and they will become primarily a domain of literary convention with a growing degree of triviality. So, it will hardly come as a surprise to anyone if it turns out that one of these metaphors appears as an ornament in the lyrics of a popular Polish lullaby, containing the phrase "when the stars are glittering with gold up in the sky"...

\section{BIBLIOGRAPHY}

Algra 1999: Algra, K. 1999. "The Beginnings of Cosmology." In The Cambridge Companion to Early Greek Philosophy. Ed. by A. A. Long. Berkeley.

Allers 1944: Allers, R. 1944. "Microcosmus. From Anaximandros to Paracelsus." Traditio 2: 319-407.

Arnheim 1974: Arnheim, R. 1974. Art and Visual Perception: A Psychology of the Creative Eye. Berkeley-London.

Bajoni 2004: Bajoni, M. G. 2004. "Gli Astronomica di Manilio come rappresentazione politica dello spazio celeste.” Latomus 63: 98-107.

\footnotetext{
${ }^{44}$ Still later, Meister Eckhart will completely reverse the relations valid in popular awareness by recognising gravel as equally precious as precious stones - everything, however, is part of the same perfection.
} 
Baldry 1952: Baldry, H. C. 1952. "Who invented the Golden Age?" Classical Quarterly 2: 83-92.

Bartol 1997: Bartol, K. 1997. "Rydwany Słońca: Mimnermos, Stezychor i inni." In Studia nad kultura antyczną. Ed. by J. Rostropowicz. Opole.

Brady 1998: Brady, E. 1998. "Imagination and the Aesthetic Appreciation of Nature." Journal of Aesthetics and Art Criticism 56.2: 139-147.

Brady 2003: Brady, E. 2003. Aesthetics of the Natural Environment. Edinburgh.

Bugaj 1991: Bugaj, R. 1991. Hermetyzm. Wrocław-Warszawa.

Buttmann 1820: Buttmann, Ph. 1820. Über das Elektron, In Abhandlungen der Königlichen Akademie der Wissenschaften in Berlin aus den Jahren 1818-1819 (Historisch-philologische Klasse). Berlin.

Clarke 2003: Clarke, J. 2003. Imagery of Colour and Shining in Catullus, Propertius, and Horace. New York.

Conger 1922: Conger, G. P. 1922. The Emergence of Microcosmic Theories in the Greek and Graeco- Roman World. In Theories of Macrocosms and Microcosms in the History of Philosophy. Ed. by G. Conger. New York.

Derrida 1974: Derrida, J. 1974. "White Mythology: Metaphor in the Text of Philosophy." Transl. by F.C.T. Moore. New Literary History 6: 5-74.

Derrida 1982: Derrida, J. 1982. "White Mythology: Metaphor in the Text of Philosophy." In Margins of Philosophy. Ed. by J. Derrida. Transl. by A. Bass. Chicago.

Eco 1987: Eco, U. 1987. Arte e bellezza nell'estetica medievale. Milano.

Finkelberg 1998: Finkelberg, A. 1998. "On the History of the Greek kóouoc.” HSCPh 98: 103-136.

Frazer 1994: Frazer, J. G. 1994. The Golden Bough: A Study in Magic and Religion (a new abridgement from the second and third editions). Oxford.

Gallagher 2001: Gallagher, R. L. 2001. "Metaphor in Cicero's De Re Publica.” Classical Quarterly 51: 509-519.

Gee 2001: Gee, E. 2001. "Cicero's Astronomy." Classical Quarterly 51: 520-536.

Gombrich 1971: Gombrich, E. 1971. "Visual Metaphors of Value in Art." In Meditations on a Hobby Horse and Other Essays on the Theory of Art by E. Gombrich. London-New York ${ }^{3}$.

Goold 1992: Manilius, Astronomica. Transl. and ed. by G. P. Goold. 1992. London.

Graves 1992: Graves, R. 1992. The Greek Myths (complete edition). London.

Guthrie 1967: Guthrie, W. K. C. 1967. "Man's Role in the Cosmos. Man the Microcosm: The Idea in Greek Thought and its Legacy to Europe.” In The Living Heritage of Greek Antiquity. Hague.

Halleux 1974: Halleux, R. 1974. Le problème des métaux dans la science antique. Paris.

Hermann 2001: Hermann, M. 2001. Obraz nieba gwiaździstego w literaturze rzymskiej epoki augustowskiej. Kraków.

Hermann 2007: Hermann, M. 2007 Metaforyka astralna w poezji rzymskiej. Kraków.

Hübner 1984: Hübner, W. 1984. "Manilius als Astrologe und Dichter.” ANRW II 32.1.

Jonas 2001: Jonas, H. 2001. The Cosmos in Greek and Gnostic Evaluation. In The Gnostic Religion by H. Jonas. Third edition. Boston.

Laks 1999: Laks, A. 1999. "Soul, Sensation, and Thought." In The Cambridge Companion to Early Greek Philosophy. Ed. by A. A. Long. Berkeley.

Landolfi 1991: Landolfi, L. 1991. "Manilio e la gerarchia delle stelle (Astr. 5. 734-745)." Prometheus 17: 247-258.

Le Boeuffle 1977: Le Boeuffle, A. 1977. Les noms latins d'astres et de constellations. Paris.

Long 1999: Long, A. A. 1999. "The Scope of Early Greek Philosophy." In The Cambridge Companion to Early Greek Philosophy. Ed. by A. A. Long. Berkeley.

Montanari Caldini 1976: Montanari Caldini, R. 1976. "L'astrologia nella traduzione Aratea di Germanico." SIFC 48: 29-117.

Olerund 1951: Olerud, A. 1951. L'idée de Macrocosmos et de Microcosmos dans le Timée de Platon. Étude de mythologie comparée. Uppsala. 
Ortony, Fainsilber 1989: Ortony, A., Fainsilber, L. 1989. "The Role of Metaphors in Descriptions of Emotions." In Theoretical Issues in Natural Language Processing. Ed. by Y. Wilks. Hillsdale. Piętka 2005: Piętka, R. 2005. Kaliope i Urania. Rzymskie poematy astronomiczne. Poznań.

Piętka 2009: Piętka, R. 2009. "Mikro- i makrokosmos w starożytności - od presokratyków do Ojców Kościoła.” In Makrokosmos versus Mikrokosmos. Ed. by A. Magowska. Poznań.

Reale 1989: Reale, G. 1989. "Lessico e indice-repertorio dei principali concetti inerenti alla filosofia antica." In Storia della filosofia antica. Volume V: lessico, indici e bibliografia by G. Reale. Co-oper. by R. Radice. Milano.

Rzepińska 1983: Rzepińska, M. 1983. Historia koloru w dziejach malarstwa europejskiego. Warszawa.

Sacchetti 1993: Sacchetti, L. 1993. "La luminosità del cielo e degli astri negli Astronomica di Manilio: osservazioni terminologiche e stilistiche." In Manilio, fra poesie e scienza. Atti di convegno di Lecce 14-16 maggio 1992. Ed. by D. Liuzzi. Lecce.

Salemme 1983: Salemme, C. 1983. Introduzione agli Astronomica di Manilio. Napoli. Santini 1977: Santini, C. 1977. Il segno e la tradizione in Germanico scrittore. Roma. Schavernoch 1983: Schavernoch, H. 1983. "Die Krone der Ariadne." AW 14: 36-52.

Semanoff 2006: Semanoff, M. 2006. "Astronomical Ecphrasis." In Musa Docta. Recherches sur la poésie scientifique dans l'Antiquité. Ed. by Ch. Cusset. Saint-Étienne.

Traglia 1984: Traglia, A. 1984. "Germanico e il suo poema astronomico." ANRW II 32.1.

Vernant 1982: Vernant, J.-P. 1982. The Origins of the Greek Thought. Ithaca-New York.

Volk 2009: Volk, K. 2009. Manilius and his Intellectual Background. Oxford.

Wagenvoort 1996: Wagenvoort, H. 1996. "La Toison d'Or." In Mélanges d'archéologie et d'histoire offerts à André Piganiol. Ed. by R. Chevallier. Vol. III. Paris.

Wright 1995: Wright, M. R. 1995. "Macrocosm and Microcosm." In Cosmology in Antiquity by M. Wright. London.

Zanker 1987: Zanker, G. 1987. Realism in Alexandrian Poetry: A Literature and Its Audience.

\section{London."WHEN THE STARS ARE GLITTERING WITH GOLD UP IN THE SKY...." GOLDSMITHERY METAPHORS IN DESCRIPTIONS OF THE SKY PHENOMENA IN ROMAN LITERATURE}

Sum mary

Metaphors and comparisons are typical features of the ancient texts describing celestial bodies, and they can be treated as a part of a broader cultural practice of seeking analogies between earth and sky phenomena, inspired by the microcosm/macrocosm theory. To explain such a practice, we can refer to the modern theory of imagination as well, according to which appreciation of nature is based, among others, on the so-called "projective imagination", transferring mentally images from terrestrial reality to the sky. One of the obvious instances of such an analogical thinking is "katasterismos", mythic narration about the item placed in the heavens as a star or constellation. It appears that among the objects in the sky described as a result of "catasterism" we can find some specimens of the jeweller's craftsmanship (e.g. Ariadne's Crown as Corona Borealis). This is, however, a specific situation; astronomical descriptions usually emphasise the brightness and perfection of the sky phenomena using the above-mentioned poetic devices associated with jewellery. Most popular among them is the metaphoric epithet of "gold", linked commonly with stars and the sun, but besides this, can be detected in the more original imagery in the works of Roman authors (e.g. the cosmos as a necklace). It is argued in the paper that this kind of astronomical description can be interpreted against the backdrop of the history of the "visual metaphors of value", as they were defined by Ernst Gombrich. 